\title{
Een cognitieve benadering van cijferanalyse
}

Prof. J.H. Blokdijk

\section{Inleiding}

In het nummer van april jl. van dit blad hebben Eimers, Biggs en Mock een artikel gepubliceerd over een zeer belangrijke procedure bij de accountantscontrole: de cijferanalyse. Dergelijke (her)beschouwingen van bij de accountantscontrole gebruikte technieken zijn van tijd tot tijd zeer verhelderend: een ander voorbeeld is de analyse die Veltman in 1988 na enige decennia van stilte alan de verbandscontrole wijdde.

Hel arlikel van Eimers. Biggs en Mock (1997) valt uiteen in twee delen: een cognitieve benadering van cijferanalyse, en een samenvatting van de bevindingen uit wetenschappelijk onderzock naar de uitvoering van cijferanalyse in de praktijk. voornamelijk in Noord-Amerika; dit lweede deel beval ook een weergave van de implicaties van die onderzoeksresultaten voor de praktijk van de accountantscontrole, hetgeen de bijdrage nog leerzamer maakı.

De cogniticve benadering van de cijferanalyse is beschreven aan de hand van een procesmodel dat is ontwikkeld door Biggs. Mock en Walkins (1988. 1989). Dit model lijkl mij echter niet geheel herkenbaar voor de - althans in Nederland in de prakiijk werkzame accountant. Daarom wil ik er enige kanttekeningen bij plaatsen.

Prof. J.H. Blokdijk is directeur van J.H. Blokdijk Advies B.V. en adviseur van ondernemingen en accountants. Daarnaast is hij hoogleraar Toegepaste Accountantscontrole aan de Vrije Universiteit Amsterdam. Hij heeft vele vaktechnische functies bij het Koninklijk NIVRA vervuld en is lid van het bestuur van de Stichting Toezicht Effectenverkeer.

\section{De plaats van cijferanalyse}

Cijferanalyse omvat in elk geval cijferbeondeling. Het doel van cijferbeoordeling die deel uitmakt van cijferanalyse is: richting geven aan de controle. Dit geschiedt door de ongecontroleerde cijfers te toetsen ain verwachtingen, waarover later méér: als dalarult afwijkingen naar voren komen. dan is de richting van de controle bekend: van die afwijkingen moet worden rastgesteld dat zij voortvloeien

- ofwel uil het feit dal de werkelijkheid zich anders heeft ontwikkeld dan verwacht,

- olwel uit een onjuiste din wel onvolledige registratie van de werkelijkheid.

De accountant gaat dus gericht op zoek; het instrument bij uitstek datarvoor is de kritische steekproef.

In de risicoanalyse bestalat het ontdekkingsrisico uil twee componenten: het cijferanalyserisico en het steekproefrisico. Als vermindering van het cijferanalyserisico iets wil bijdragen alan de vermindering van het ontdekkingsrisico, dan moet met cijferanalyse iets ontdeki kunnen worden. Als cijferanalyse méér omvat dan cijferbeoordeling. dan moet dat meerdere ten minste een maatregel onvilten waarmee iets ontdekt kan worden. Omdat cijferbeoordeling beoogt richthing gevend te zijn. zou dic maatregel de gerichte steekproet moeten zijn. Cijferanalyse wordt dan een zeer krachtig controlemiddel.

Het beslissingsproces van Biggs. Mock en Watkins als beschreven in hel arlikel van Eimers, Biggs en Mock lijkt echter zo ver niet te gaan, althans niet expliciet. Zo refereren zij aan een bevinding van Anderson en Koonce (1995). 
waaruit blijkt dat accountants de door cliënten gegeven verklaringen van afwijkingen niet altijd trachten in geld te vertalen, en dan soms niet ontdekken dat die verklaring ontoereikend is. Welnu, als cijferanalyse niet verder reikt dan het aanhoren van verk laringen van cliënten en het $k$ wantificeren van derzelver betekenis, dan dient cijferanalyse kennelijk niet om richting te geven alan de controle, maar om deze te verrangen! Verklaringen van de cliënt kunnen wel degelijk verder richting geven aan de controle. maar om iets te ontdekken moet de accountant die verklaringen verifiëre'n. Het onderzoek van Anderson en Koonce toont aan dat accountants zich wel eens in de luren laten leggen.

\section{Enkele elementen uit het beslissingsproces}

Ook de detailstappen van het door Biggs. Mock en Watkins ontwikkelde procesmodel hebben enkele voor Nederlandse accountants opvallende kantjes.

Bij het ontwikkelen van de verwachtingen waarmee de ter controle voorgelegde cijfers worden beoordeeld. wordt met geen woord gerept over budgetten en begrotingen, noch in positieve, noch in negatieve zin. Nu is in Nederland wel eens de onjuiste indruk gewekt dat budgetten en begrotingen voor de accountantscontrole "normatieve gegevens' zijn waaraan de getrouwheid van de verantwoording zou kunnen worden getoetst: de ontmaskering van deze denkfout behoeft er echter niet toe te leiden dat aan budgetten en begrotingen bij de cijferbeoordeling geen enkele betekenis wordt toegekend. Juist in het kader van de ontwikkeling van de verwachtingen bij cijferbeoordeling kunnen zij van betekenis zijn, zij het dat er dan nog enkele aanvullende stappen moeten worden genomen. Zo moeten budgetten en begrotingen niet alleen procedureel maar ook inhoudelijk worden getoetst, met name om vast te stellen in hoeverre zij een goede basis voor de verwachtingen bieden. Budgetten zijn nogal eens taakstellend. en dus - al dan niet lichtelijk - gekleurd; dan zijn afwijkingen vrijwel onvermijdelijk, en in elk geval weinig richtinggevend. Begrotingen, in de zin van 'best estimates', zijn dan in beginsel beter bruikbaar. maar zij zijn vaak globaler en later beschikbaar dan budgetten. Bij passend gebruik zijn beide instrumenten echter toch nuttig bij de cijferbeoordeling.
Een ander opvallend element in het procesmodel is de kennelijke onontbeerlijkheid van hypothesen. Bij het aantreffen van afwijkingen bij een cijferbeoordeling moeten accountants eerst brainstormen over mogelijke verklaringen, en gaan dan de meest plausibele hypothese(n) toetsen. De ontwikkeling van hypothesen is een exercitie achter het burealu; het procesmodel laat geen ruimte voor de accountant die zijn hemdsmouwen opstroopt en gewoon gaat uitzoeken waar de afwijking uit bestait en/of wat deze heeft veroorzaakt. Het uiteindelijk doel van cijferanalyse is, dat er iets wordt ontdekt; ontdekken kan echter ook zonder hypothese. Een cynische vertaling van hypothese is: vooroordeel; Eimers. Biggs en Mock geven zelf aan dat hypothesen soms bewustzijnsvernauwend werken ( $p$. 176 rechtsonder/p. 177 linksboven). Hun model voor het cijferanalyseproces lijkt mij te exclusief geënt op een wetenschappelijk onderzoeksmodel.

\section{Slot}

Desondanks vind ik het artikel van Eimers, Biggs en Mock zeer belangwekkend. De beschouwing zou echter verrijkt kunnen worden indien de cijferbeoordeling iets meer vanuit de praktijk zou worden beschouwd; het geheel doet iets te veel aan de studeerkamer denken. Die indruk wordt versterkt door de vergelijking die de auteurs maken van de cijferanalyse met een onderzoek van een pattiënt door een arts. Zij stellen: 'De arts verricht een aantal onderzoeken en vergelijkt de resultaten ervan met de verwachtingen die hij heeft van een gezond persoon.' Gelukkig doet mijn arts dat niet: die vergelijkt de onderzoekresultaten met bekende ziektebeelden. Maar de vergelijking gaat helemáal mank: de "cijferbeoordeling" doet een arts bij het aanhoren van mijn verhaal en het aanzien van mijn verschijning: op grond daarvan beslist hij of, en welke, onderzoeken hij moet (laten) doen.

Misschien kunnen vorenstaande suggesties bijdragen tot een nog robuuster procesmodel voor de cijferanalyse. Het reeds verrichte werk acht ik stellig waardevol. 


\section{I T E R A T U U R}

Anderson, U. en Koonce, L., (1995), Explanations as a Method for Evaluating Client-suggested Causes in Analytical Procedures, Auditing, a Journal of Practice and Theory (Fall), pp. 125-132.

Biggs, S.F., Mock, T.J. en Watkins, P.R., (1988), Auditors' use of Analytical Review in Audit Program Design, The Accounting Review, pp. 148-161.
Biggs, S.F., Mock, T.J. en Watkins, P.R., (1989), Analytical Review Procedures and Processes in Auditing. The Canadian Certified General Accountants Foundation, Vancouver, Canada.

Eimers, P.W.A., Biggs, S.F. en Mock, T.J., (1997), Oordeelsvorming bij cijferanalyse, conclusies uit cognitief onderzoek, Maandblad voor Accountancy en Bedriifseconomie, april, pp. 171-180.

Veltman, P., (1988), Verbandscontrole als controlemiddel van de accountant, Maandblad voor Accountancy en Bedrijfseconomie, mei, pp. 203-216. 